\title{
Electronic Word of Mouth as a Marketing Communication Tool Agains Brand Attitudes and Purchase Intention
}

\author{
Rurry Citra Devianti ${ }^{1}$, Irwansyah $^{2}$ \\ $\left\{{ }^{1}\right.$ rurrycitra@gmail.com, ${ }^{2}$ dr.irwansyah.ma@gmail.com $\}$ \\ ${ }^{1}$ STIKOM, Indonesia \\ ${ }^{2}$ Universitas Indonesia, Indonesia
}

\begin{abstract}
The purpose of this research is to find out and analyze electronic word of mouth (eWOM) in social media Instagram, can influence brand attitude and purchase intention in lipstick brand By Lizzie Parra (BLP). BLP is a lipstick product that was born through a digital store first, and then they opened its offline stores which are now spread in three cities in Indonesia. This research was conducted by using a quantitative method with convenient sampling while data were collected from scaled questionnaire through using the online survey. The use of this method isn't only illustrates the concepts and facts that exist, but intends to analyze and explain the causal influence between the variables through hypotheses testing. The sample in this study totaled 110 respondents, the sampling technique was taken random with the criteria of female that having an Instagram social media account, also knowing BLP lipstick products. Data were analyzed using a variance-based Structural Equation Model (SEM), using the Analysis of Moment Structures (Amos). Word of mouth significantly it has a strong influence on brand attitude and purchase intention.
\end{abstract}

Keywords: Electronic Word of Mouth, Marketing Communication, Brand Attitude, Purchase Intention.

\section{Introduction}

Word of mouth electronics (ewom) developed rapidly and were adopted in marketing communication strategies. e-wom is also considered as the most dominant factor that can influence consumer purchasing decisions (Bataineh, 2015) Customers who are satisfied after buying or using services or products, they will have the right to share their experiences with others, specifically for those closest to them (Kotler \& Armstrong, 2001).

So this communication channel can be one of the most effective promotional methods because it can be used for advertising for companies, this method also does not require a large cost because by connecting customers who will provide the products or services obtained, then the service or product can be easily distributed to other consumers (Christy, 2010). Marketing communication via ewom is also widely used to communicate the products of a brand, one of which is the marketing phenomenon in lipstick products which are then born or started from a digital store. Because the level of need and purchase of cosmetics, making this cosmetics business grow fast every year, cosmetic products have become one of the primary needs for women to beautify and maximize their appearance (Dwiwahjono, 2019).

Indonesia is a potential market for cosmetics industry entrepreneurs both from outside and within the country. The national cosmetics industry experienced an increase from $6.35 \%$ in 
2017, to $7.36 \%$ in the first quarter of 2018. Domestically, the Cosmetics Industry increased by 153 companies in 2017, bringing the total to 760 companies (Hartarto, 2018). This increase was driven by increased domestic or foreign market demand. In 2017, the export value of national cosmetic products rose to US $\$ 516.99$ million, up by $16 \%$ compared to 2016 which was only US \$ 470.30 million (Dwiwahjono, 2019).

In line with the development of this cosmetics industry, the government also participated in supporting, by issuing Government Regulation No. 14 of 2015: Rencana Induk Pembangunan Industri Nasional (RIPIN) for 2015-2035 which states that, the cosmetics industry is one of the mainstay industries (priority industries) as the "Prime Mover" of the economy. Industrial development will also be focused on 11 industry groups, one of which is the cosmetics industry.

For the cosmetics market currently still dominated by decorative cosmetics for lips or commonly referred to as lipstick, the article is a cosmetic item that must be owned by women today with a contribution value of $64 \%$ in urban areas and $75 \%$ in rural areas (Nielsen, 2013). Statistical data also explains that from 2014 to May 2017, 44\% of cosmetics launched in Indonesia were lip cosmetic products (Statista, 2018).

The growth of the industry cannot be separated from the incessant marketing through social media. Utilization of digital technology starting from the production process to distribution to consumers through e-commerce, provides new opportunities and increases the competitiveness of the national cosmetics industry with changes in consumer tastes and lifestyles that are fairly fast changing (Dwiwahjono, 2019).

Cosmetics brands must also be able to develop marketing communication patterns and encourage the trust and interest of consumers to engage and engage with their brand conversations, cosmetics brands must design creative and innovative strategies in utilizing social media to reach their maximum potential to encourage consumer buying interest (Rosanna, 2018). So consumer involvement is so important as an effort to broaden conversations related to marketing content that can be done through social media (Marci, 2017).

As many as $52 \%$ of internet users in Indonesia currently tend to trust advertising and recommendations on social media, even $30 \%$ of consumers in Indonesia have been involved in brand conversations and forward the link to articles related to brands or products. This percentage is quite potential, considering that on average only $19 \%$ of consumers in the world are willing to make links related to digital advertising content (Statista, 2018).

So this study tries to identify the potential of e-wom on SNS (Social Networking Sites) platforms on social media such as Instagram, as a form of marketing communication that can lead to Purchase Intention and attitudes towards the By Lizzie Parra (BLP) lipstick brand. So that the formulation of the problem in this study is: How Electronic Word of Mouth As a Marketing Communication Tool Against Brand Attitudes and Purchase Intention in BLP Lipstick?

\section{Theoritical Background}

\subsection{Electronic Word of Mouth}

Ewom has become an important factor in shaping consumer purchases. Product reviews posted by customers on the internet are one of the most important and common forms of ewom communication for consumers today to find product reviews and comments from their 
peers in the online media for compiling pre-purchase product information (Farzin \& Fattahi, 2018).

Ewom occurs between people who have little or no prior relationship and may even be anonymous. This anonymity allows consumers to share their opinions comfortably and freely with other people they did not know before, and helps create new social relationships (Lee and Youn, 2009). Helping currently plays a role in creating, creating and developing ewom independent of a marketer. The same thing is realized by companies, ewom has become a special marketing tool (Zaheer, 2015).

\subsection{Brand Attitude}

Attitudes towards brands present the influence of consumers on a brand, which can lead to concrete actions such as the choice of a brand (Kurniawati, 2009). Brand attitude is also defined as an overall evaluation of the brand carried out by consumers and reflects the consumer's response to the brand. Brand attitude is associated with trust in related attributes such as function and experience. In general, brand attitude can be measured through the strength and direction of associations with certain brands (Keller, 1998)

The more positive the consumer's attitude towards a brand, the more consumers' behavior and intention towards the brand will be more positive (Wilkie, 1994). A consumer's positive brand attitude towards a brand will enable consumers to make purchases, while a negative brand attitude will prevent consumers from making purchases (Chang, 2008).

\subsection{Purchase Intention}

Purchasing interest is important in consumer behavior because the greater the buying interest in a consumer, the greater the opportunity for the buying process (Toor, Husnain, \& Hussain, 2017). Market research companies often use purchase intentions to estimate the potential for new product sales. In addition, purchase intention measures have often been used to identify the possibility of buying a product within a specified time period (Asshidin et al, 2016).

Consumer buying interest is formed from the integration that occurs between factors that are sustainable between consumers and products or services. If someone has a high interest in a product, that person will definitely look for complete information about the goods and services but otherwise if the person is not too interested in the product, they will be indifferent (Imelia \& Ruswanti, 2017; Schiffman \& Kanuk, 2004 ).

It's important to understand how Internet consumers are motivated to make a purchase, find product-related information based on personal judgment and environmental factors, then evaluate and compare several potential products before finally deciding which one to buy online (Teng et al, 2016)

\subsection{Conceptual Framework and Hypotheses}

The conceptual framework of the study is outlined in Figure 1. Considering past studies, the framework was built on prevalent ideas on social eWOM (Bambauer-Sachse and Mangold, 2011; Jalilvand and Samiei, 2012a, 2012b), brand attitude (Schivinski and Dabrowski, 2014; Tang et al., 2011) and purchase intention (Schivinski and Dabrowski, 2014; Yoo et al., 2000; Shukla, 2011). 
H1: There is an Effect of Electronic Word of Mouth as a Marketing Communication Tool Against Brand Attitudes.

H2: There is the Effect of Electronic Word of Mouth as a Marketing Communication Tool Against Purchase Intention.

H3: There is an Effect of Electronic Word of Mouth as a Marketing Communication Tool Against Brand Attitudes and Purchase Intention.

\section{Research Methodology}

This study uses quantitative research objects on lipstick products by Lizzie Parra (BLP). Lipstick was chosen as the top cosmetic product representation (80\%) used by women in Indonesia (YouGov, 2016). Data from statistics were also announced in 2014 to May 2017, $44 \%$ of cosmetics launched in Indonesia are lipstick cosmetic products (Statista, 2018). The purchase intention on the purchase intention on this product is very potential for evaluation as an object of research.

While for research subjects to be made as sources of individual research respondents are consumers who have a genre of women, find lipstick brands by Parra (BLP), have social media accounts such as Instagram, Facebook, or Twitter, as well as active social media users, in this case active users can be asked to actively spend between 2-4 hours a day to access social media (Bisnis Indonesia, 2018).

Thus, representing in this study a representative sample was chosen to represent the population. Determination of the number of samples calculated based on the formula from Hair et al (2006) where the minimum sample size recommended in the use of Structural Equation Model (SEM) is as much as 100-200 or using 5-10 times the number of observations for each user used.

In this study the non-probability research sample method was used with purposive sampling. Data collection in this study was carried out through field research techniques or surveys using a questionnaire with a Likert 1-5 measurement scale, which is a data collection instrument by transferring online questionnaires to active social media users with the aim of obtaining information relevant to the research problem. The questionnaire link is then copied and sent to respondents via social media such as Instagram, so that respondents easily and voluntarily answer questions in filling out the questionnaire.

The questionnaire was designed into three parts, the first part consisted of filtered questions, filtering questions confirmed respondents whether the respondents were female, and had a social media account. This is done to ensure that only people who fit the criteria can fill out the survey. The second part of the questionnaire contains demographic data by asking for personal identity. Then the third part of the questionnaire contains questions and statements related to the three variables studied namely electronic word of mouth (BambauerSachse \& Mangold, 2011), Brand attitude (Schivinski \& Dabrowski, 2014), Purchase Intention (Schivinski \& Dabrowski, 2014).

In this research, descriptive analysis will be carried out to describe the data obtained. Then the data were analyzed using the Structural Equation Model (SEM) using the Analysis of Moment Structures (Amos). 


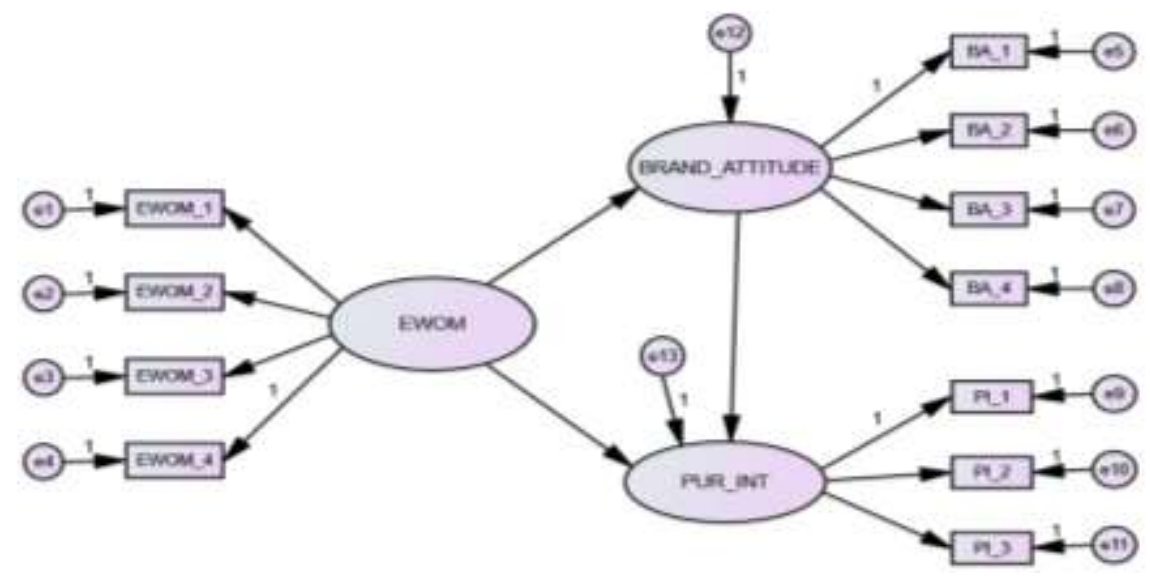

Figure 1. Structural Equation Model (SEM) specification

\section{Research Results And Discussion}

The results of this study describe the Electronic Word of Mouth as a Marketing Communication Tool that causes Brand Attitudes and Purchase Interests which are carried out in several stages such as the distribution of questionnaires by testing 30 respondents to test the reliability and validity where the following results are obtained:

\subsection{Testing the Assumptions of the Structural Equation Model}

The process of testing the requirements analysis in this study is a requirement that must be met so that the use of regression techniques included in the parametric statistical group can be applied for the purposes of hypothesis testing. Testing the requirements analysis performed is the normality of the regression error.

Testing the error normality requirements in the Structural Equation Model (SEM) is done with a view to knowing whether the data distribution does not deviate from the characteristics of normally distributed data. This normality requirement test is performed on univariate and multivariate estimated error based on the output of the amos application analysis. Testing the normality of errors in the SEM model is tested through the following hypothesis:

$\mathrm{H}_{0}$ : error in SEM model has normal distribution

$\mathrm{H}_{1}$ : errors in the SEM model are not normally distributed

Decision making provisions if the value of the critical ratio (c.r.) is located at intervals of -2.58 to 2.58 , it does not reject $\mathrm{H} 0$, meaning that the estimated error in the SEM model is normally distributed. The normality test results of structural equation model path diagram of structural models based on the output of the amos output are listed in Table 1 below, the lowest c.r univariate value is $-1,156$ and the highest is 2,201 (column 5). These values are at intervals of $-2.58<\mathrm{c} . \mathrm{r}<2.58$, so do not reject $\mathrm{H} 0$ or model errors in the normal distribution structural equation (Reference). Thus, it can be concluded that the errors in the SEM model formed are normally distributed. 
Table 1. Testing error normality structural equation model

\begin{tabular}{|l|rrrrrr|}
\hline Variable & $\min$ & $\max$ & skew & c.r. & kurtosis & c.r. \\
\hline PI_3 & 2.000 & 5.000 & -.305 & -1.376 & -1.122 & -2.530 \\
PI_2 & 1.000 & 5.000 & -.477 & -2.153 & -.247 & -.556 \\
PI_1 & 2.000 & 5.000 & -.352 & -1.586 & -.991 & -2.235 \\
EWOM_1 & 2.000 & 5.000 & -.750 & -3.380 & -.403 & -.910 \\
EWOM_2 & 2.000 & 5.000 & -1.040 & -4.691 & .398 & .898 \\
EWOM_3 & 1.000 & 5.000 & -1.410 & -6.358 & 2.201 & 4.962 \\
EWOM_4 & 2.000 & 5.000 & -1.028 & -4.637 & .450 & 1.014 \\
BA_4 & 2.000 & 5.000 & -.255 & -1.150 & -.748 & -1.687 \\
BA_3 & 2.000 & 5.000 & -.128 & -.577 & -1.040 & -2.344 \\
BA_2 & 3.000 & 5.000 & -.117 & -.528 & -1.156 & -2.606 \\
BA_1 & 2.000 & 5.000 & -.203 & -.917 & -1.065 & -2.402 \\
Multivariate & & & & & 48.554 & 15.856 \\
\hline
\end{tabular}

\subsection{Parameter Estimation and Parameter Testing}

Testing the estimating coefficient of the parameters of the structural equation model indicator is done through testing the following hypotheses:

$$
\begin{aligned}
& \mathrm{H} \_0_{0}: \mathrm{b} \_1_{-}=\mathrm{b} \_2_{2}=0 \\
& \mathrm{H} \_1_{-}: \text {there is one different value of } \mathrm{b}
\end{aligned}
$$

Testing Conditions. if the value of sig. $\alpha=0.05$. then reject $\mathrm{H} 0$ or the estimation coefficient is significant at the real level $\alpha$. Based on Table 2, all of the ewom indicators, brand attitude indicators and purchase intention indicators have a P-value less than $\alpha$ of 0.05 , then reject H0. Thus it can be concluded that the ewom indicator, brand attitude indicator and purchase intention indicators significantly influence the latent variables of ewom, brand attitude and purchase intention directly at the real level of $5 \%$.

The ewom parameter to the bran attitude is 0.477 with a p-value of $0.000<\alpha$ of 0.05 , so reject H0. That is, ewom has a direct effect on brand attitude and is real at the $5 \%$ level. Then ewom latent variable parameters to the purchase attitude of 0.081 with a p-value of $0.289>\alpha$ of 0.05 , it does not reject H0. That is, ewom does not directly influence the purchase intention at a real level of $5 \%$. While the brand attitude parameter on purchase intention is 0.934 with a p-value of $0.000<\alpha$ of 0.05 , then reject $\mathrm{H} 0$. That is, brand attitude has a direct effect on the purchase and is significant at the $5 \%$ level.

Table 2 Estimating the Parameters and Testing the Parameters

\begin{tabular}{|lll|rrrr|}
\hline & & & Estimate & S.E. & C.R. & P \\
\hline BRAND_ATTITUDE & $<---$ & EWOM & .446 & .095 & 4.679 & $* * *$ \\
PUR_INT & $<--$ & EWOM & .081 & .076 & 1.060 & .289 \\
\hline
\end{tabular}




\begin{tabular}{|c|c|c|c|c|c|c|}
\hline & & & Estimate & S.E. & C.R. & $\mathrm{P}$ \\
\hline PUR_INT & $\begin{array}{l}<-- \\
\end{array}$ & BRAND_ATTITUDE & 934 & .114 & 8.170 & **** \\
\hline BA_1 & $<--$ & BRAND_ATTITUDE & 1.000 & & & \\
\hline BA_2 & $<--$ & BRAND_ATTITUDE & .925 & .100 & 9.231 & $* * *$ \\
\hline BA_3 & $<--$ & BRAND_ATTITUDE & 1.261 & .140 & 9.000 & $* * *$ \\
\hline BA_4 & $<--$ & BRAND_ATTITUDE & 1.247 & 132 & 9.415 & **** \\
\hline EWOM_4 & $<--$ & EWOM & 1.000 & & & \\
\hline EWOM_3 & $<--$ & EWOM & 1.063 & .099 & 10.759 & $* * *$ \\
\hline EWOM_2 & $<--$ & EWOM & 987 & .093 & 10.658 & $* * *$ \\
\hline EWOM_1 & $<--$ & EWOM & .983 & .093 & 10.610 & $* * *$ \\
\hline PI_1 & $<--$ & PUR_INT & 1.000 & & & \\
\hline PI_2 & $<--$ & PUR_INT & 1.190 & .115 & 10.323 & **** \\
\hline PI_3 & $<--$ & PUR_INT & 1.176 & 106 & 11.129 & $* * *$ \\
\hline
\end{tabular}

In addition, the results of the estimation of the SEM model parameters are presented in Figure 2 below:

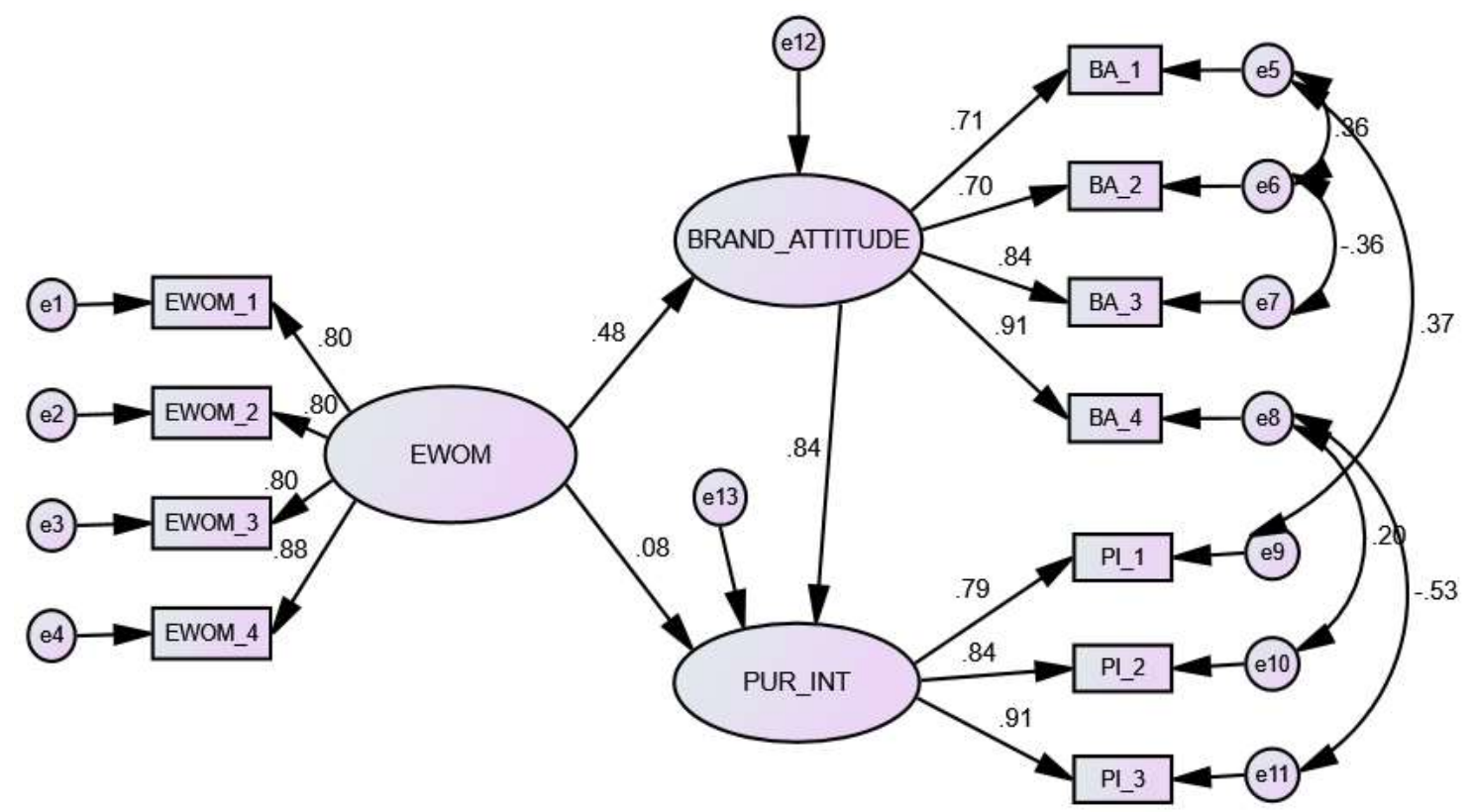

Figure 2. Reliability Specifications for the Second Structural Equation Model

\subsection{Testing the Goodness of the Second Structural Equation Model}

The goodness of the second structural equation model can simultaneously be determined from the magnitude of some goodness of fit values listed in Table 6. Conditions for testing the 
chi square value. if the value of $X \_$count ${ }^{\wedge} 2$ is small or <table. then the model is decent. Next. if the value of sig. $>\alpha=0.05$. then the model is decent. Other than that. the model is said to be feasible if it has an RMSEA value $\leq 0.08$. GFI and AGFI $\geq 0.90$ and TLI and CFI values $\geq 0.95$.

Based on Table 3, the value of X_count ${ }^{\wedge} 2$ is 49,799 which is smaller than t_table of 50.99. The significance value of 0.063 is greater than $\alpha$ of 0.05 . The RMSEA value of 0.056 is smaller than the value of 0.08 . The GFI value of 0.929 is greater than the critical value of 0.90 . The AGFI value of 0.870 is smaller than the critical value of 0.90 . Then. TLI and CFI values of 0.977 and 0.985 are greater than the critical value of 0.95 . This means that all measures of model goodness already meet the value of criticism except AGFI criteria. Thus it can be concluded that the second structural equation model simultaneously is feasible to use.

Table 3. Goodness of Fit Model Second Structural Equation

\begin{tabular}{llll}
\hline \multicolumn{1}{c}{ Goodness of Fit Index } & \multicolumn{1}{c}{ Cut off Value } & NilaiHitung & Keterangan \\
\hline $\mathrm{X}^{2}-$ Chi Square & kecil & $49.799<50.99$ & good fit \\
Significant Probability & $\geq 0.05$ & 0.063 & good fit \\
RMSEA & $\leq 0.08$ & 0.056 & good fit \\
GFI & $\geq 0.90$ & 0.929 & good fit \\
AGFI & $\geq 0.90$ & 0.870 & poor fit \\
TLI & $\geq 0.95$ & 0.977 & good fit \\
CFI & $\geq 0.95$ & 0.985 & good fit \\
\hline
\end{tabular}

\section{Conclusion}

From the results of research and discussion, a conclusion can be drawn as follows

1. Ewom directly affects the brand attitude of BLP lipstick products. And it is significant at the $5 \%$ level.

2. Brand attitude directly influences the buying interest of lipstick products and is significant at the $5 \%$ level.

3. Ewom simultaneously influences brand attitud and buying interest in lipstick consumers.

\section{References}

[1] Bataineh, Abdallah, Q. (2015). The Impact of Perceived e-WOM on Purchase Intentio: The mediating Role of Corporate Image. International Journal of Marketing Studies; Vol. 7 No.1;2015.

[2] Babbie, E. (2004). The Practice of Social Research 10th Edition. California: Thomson Wadsworth.

[3] Bambauer-Sachse, S. and Mangold, S. (2011), "Brand equity dilution through negative online word-of-mouth communication", Journal of Retailing and Consumer Service, Vol.18 No. 1, pp. 38-45. 
[4] Christy M.K. Cheung, Dimple R. Thadani. (2010). The Effectiveness of Electronic Wordof-Mouth Communication: A Literature Analysis. 23rd Bled eConference eTrust: Implications for the Individual, Enterprises and Society June 20-23, 2010; Bled, Slovenia.

[5] Dwiwahjono, 2019 diakses dari: www.katadata.co.id.

[6] Farzin Milad, Fattahi Majid. (2018) "eWOM through social networking site and impact on purchase intention and brand image in Iran”. Journal of Advances in Management Research, Vol. 15 Issue: 2, pp. 161-183.

[7] Hartarto, 2018 diakses dari: https://kemenperin.go.id/artikel/18957/industri-kosmetiknasional-tumbuh-20\%25.

[8] Keller, Kevin Lane (1998), Strategic Brand Management, Upper Saddle River, NJ: Prentice-Hall.

[9] Kotler, Philip, dan Gary, Amstrong.2001. Prinsip-Prinsip Pemasaran. Penerjemah Imam Nurmawan. Jakarta: Penerbit Salemba Empat.

[10] Kudeshia, C. and Kumar, A. 2016. Social eWom: does it affect the brand attitude and purchase intetion of brands. Management Research Review. Vol. 40 No. 32017.

[11] Lee, M. and Youn, S. (2009), “ Electronic word of mouth (eWOM) How eWOM platforms influenceconsumer product judgment”, International Journal of Advertising, Vol. 28 No.3, pp. 473-499.

[12] Rencana Induk Pembangunan Industri Nasional (RIPIN) tahun 2015-2035 Diakses dari: https://kemenperin.go.id/ripin.pdf.

[13] Schiffman, leo n. and Kanuk, Leslie Lazar.2004. Perilaku Konsumen (edisi ke tujuh. PT Indeks Jakarta.

[14] Schivinski, B. and Dabroeski, D. (2014), "The Effect of social media communication on consumer perceptions of brands", Journal of Marketing Communications, Vol.9 No.1, pp.1-26.

[15] https://id.yougov.com/id/news/2016/12/02/make-up-culture-id/.

[16] https://katadata.co.id/berita/2018/02/19/pengguna-internet-indonesia-paling-sukachatting-dan-media-sosial. 